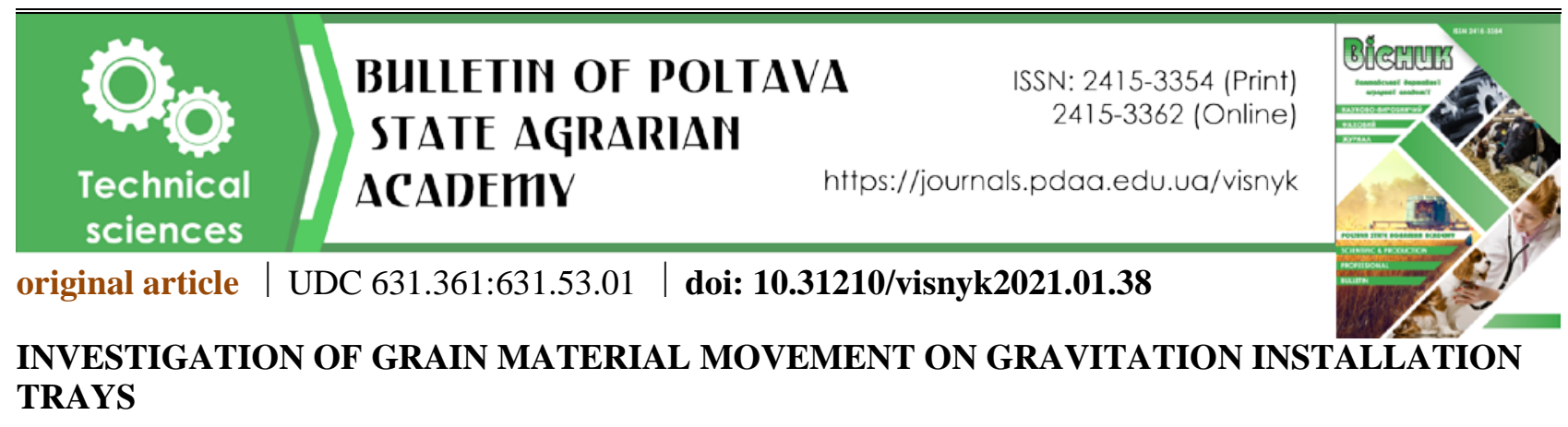

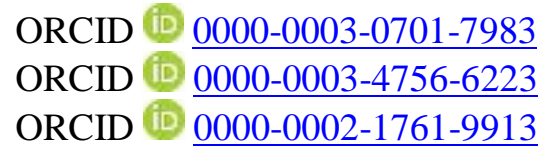

Poltava State Agrarian Academy, 1/3, Skovorody str., Poltava, 36003, Ukraine

*Corresponding author

E-mail: oleegivanov@yahoo.com

How to Cite

Arendarenko, V. M., Samoilenko, T. V., \& Ivanov, O. M. (2021). Investigation of grain material movement on gravitation installation trays. Bulletin of Poltava State Agrarian Academy, (1), 302-309. doi: 10.31210/visnyk2021.01.38

Various technological operations are widely used at elevator enterprises. They include such operations as: sorting, separating, drying, transporting, and loading of silos with grain. For the rational using of these and other processes, it is necessary to take into account the possibility of interacting grains with each other and working devices of machines. This interaction depends on the nature of grain material movement both on the surfaces of working parts of the relevant equipment and in devices for performing secondary operations connected with grain transportation to silo loading openings and the loading itself. Insufficient consideration of the peculiarities of grain flow movement can result in violating technological modes of elevator operating and, consequently, the quality of grain products stored in silos deteriorates. The technological process of loading silos with grain material, using open spiral loaders, takes place in the mode of rapid gravitation motion. A principal feature of this type of movement is the presence of conditions for rapid moving of grains in grain layer. As a result of it, grains acquire a significant speed of chaotic movement. The work was aimed at identifying structural and kinematic characteristics of gravitation flows in an installation with discrete variable slope angles of acceleration and brake trays. The main tasks of the work were laboratory study of wheat, corn and sunflower seed movement in U-shaped trays in order to establish the actual time of grain material movement in both the accelerator and brake trays. The trays were made of rolled steel, had the same length and roughness. Such studies using the gravitation installation are necessary to detect the rate of accelerating and breaking loose grain material of standard moisture content. It has been found that for the effective operation of the gravitation installation it is necessary that the inclination angle of the acceleration tray was much larger than the angle of the natural slope of grain material. Whereas, the inclination angle of the brake tray must be 1.22 times bigger than the angle of grain natural slope. Such ratio of angles makes it possible to obtain the movement of grain material in the brake tray at almost a constant linear speed, without a sharp increase in the mass and volume of grain load in this area.

Key words: installation, acceleration and brake trays, inclination angles, grain, time of descent.

\title{
ДОСЛІДЖЕННЯ РУХУ ЗЕРНОВОГО МАТЕРІАЛУ ПО ЛОТКАМ ГРАВІТАЦІЙНОЇ УСТАНОВКИ
}

\section{В. М. Арендаренко, Т. В. Самойленко, О. М. Іванов}

Полтавська державна аграрна академія, м. Полтава, Україна

На елеваторних підприємствах широко використовують різні технологічні операції. До них відносяться такі операції, як сортування, сепарація, сушіння, транспортування $і$ завантаження силосів зерном. Для раџіонального використання цих та інших прочесів необхідно враховувати можливості 


\section{TEХHІЧНI НАУКИ}

взаємодї зернин між собою і робочими органами машин. Така взаємодія залежить від характеру руху зернового матеріалу як по поверхням робочих органів відповідного обладнання, так і у пристроях для виконання допоміжних операчій, пов'язаних із транспортуванням зерна до завантажувальних отворів силосів, та саме завантаження. Недостатнє врахування особливостей руху зернових потоків може призвести до порушення технологічних режимів функціювання елеватора $i$, як наслідок, погіршується якість зернової продукиії, яка зберігається в силосах. Технологічний процес завантаження силосів зерновим матеріалом з використанням відкритих спіральних завантажувачів відбувається в режимі швидкого гравітаційного руху. Принциповою особливістю такого роду руху є наявність умов швидкого зсуву зернин у зерновому шарі. В результаті такого руху зернини суттєво пришвидиуються і хаотично перемішуються. Метою роботи було виявити структурно-кінематичні характеристики гравітаційних потоків в установиі з дискретно змінними кутами нахилу розгінного і гальмівного лотків. Основними завданнями роботи є лабораторне дослідження руху насіння пшениці, кукурудзи та соняшнику в U-подібних лотках для того, щоб установити фактичний час руху зернового матеріалу як у розгінному, так $і$ в гальмівному лотках. Лотки виготовлені зі сталевого прокату, мають однакову довжину та шорсткість. Такі дослідження з використанням гравітаційноі установки необхідні для виявлення темпу розгону і гальмування сипкого зернового матеріалу стандартної вологості. Встановлено, щзо для ефективної роботи гравітаиійної установки необхідно, щоб кут нахилу розгінного лотка був набагато більшим від кута природного відкосу зернового матеріалу. Тоді як кут нахилу гальмівного лотка повинен бути в 1,22 раза більшим від кута природного відкосу зерна. Таке співвідношення кутів дає можливість отримати рух зернового матеріалу в гальмівному лотку практично з постійною лінійною швидкістю без різкого збільшення маси і об'єму зернового вантажу на иій діляниі.

Ключові слова: установка, розгінний і гальмівний лотки, кути нахилу, зерно, час спуску.

\section{Вступ}

У сільському господарстві виробляється і переробляється різноманітне насіння зернобобових культур. Більшість цього зерна в Україні переробляється і зберігається на великих елеваторних підприємствах. При надходженні зерна на елеватори воно підлягає певним технологічним операціям, які пов'язані із сортуванням, сушінням, сепарацією, транспортуванням та завантаженням його в силоси.

Однією з проблем $є$ те, що завантаження силосів зерновим матеріалом відбувається через потенціальну енергію падаючого на дно силосу зерна. Таке завантаження призводить до того, що в нижній частині силосу накопичується бите або травмоване зерно [4-7, 11, 12, 15, 21, 23].

Для зменшення травмування зерна вчені пропонують різні гальмівні пристрої $[10,25]$, котрі зменшують енергію руху зернового матеріалу. Ми в роботі [8] запропонували спіральний завантажувальний пристрій зі змінними кутами нахилу гвинтової лінії.

Для раціональної організації спуску зернового матеріалу по цьому пристрою необхідно враховувати взаємодію зернових частинок потоку $[16,19,26]$, яка залежить від характеру руху по робочому органу пристрою, так і від кутів нахилу гвинтової лінії. Недостатне врахування особливостей руху зернового вантажу при проєктуванні завантажувальних пристроїв такої конструкції може призвести до порушення технологічного процесу зберігання зерна в силосі, Травмоване зерно в нижній частині циліндричної ємності має знижену стійкість при довготривалому зберіганні $[5,10,13,24]$.

При завантаженні силосів зерном спостерігається таке явище, як сегрегація [11, 13, 20, 25]. Вона, як правило, з'являється при гравітаційному завантаженні силосів компактним струменем. Це означає, що більш крупні й округлені зернівки скочуються до внутрішньої стіни силосу, тоді як дрібні накопичуються на середині зернового насипу. Утворення такого насипу знижує міцність силосної споруди $[5,11,22]$, що своєю чергою впливає на стабільність зберігання і випуску зернового матеріалу, а як наслідок якість кінцевого продукту знижується.

Багато технологічних процесів 3 переміщення зернового матеріалу відбувається в умовах швидкого гравітаційного руху $[1-3,9,14,21,23]$. Принциповою особливістю такого роду зернових потоків $\epsilon$ наявність умови швидкого зсуву зернин, у результаті чого зернини набувають лінійних і кутових швидкостей з хаотичним переміщенням їх в зерновому шарі потоку $[1,13,14]$.

Швидкі гравітаційні потоки супроводжуються активною взаємодією окремих зернин одна 3 одною, внаслідок такої дії з'являються нові технологічні ефекти, пов'язані зі змішуванням і розділенням.

Тому з метою вивчення структурно-кінематичних характеристик швидких гравітаційних потоків у 
завантажувальних пристроях зі змінними кутами нахилу до горизонту необхідно розробити і виготовити гравітаційну лабораторну установку такого типу.

Мета роботи - необхідність оптимізувати кути нахилу розгінної і гальмівної ділянок відкритого сегментного каналу гравітаційної установки.

Завдання досліджень:

1. Виготовити лабораторну установку з розгінною і гальмівною ділянками руху зернового матеріалу в силовому полі Землі.

2. Дослідити час руху різного зернового вантажу відповідно по розгінному і гальмівному каналах.

\section{Матеріали і методи досліджень}

Дослідження швидкого гравітаційного руху зернових матеріалів проводили в лабораторії кафедри технології та обладнання переробних і харчових виробництв Полтавської державної аграрної академії. В дослідженнях використовували лабораторну установку (рис. 1), котра складалась з бункера для зберігання зерна 1, розгінного 2 і гальмівного 3 лотків, які у своєму перерізі мають форму сегмента, при цьому кут нахилу лотків відносно горизонту можна змінювати за допомогою вертикальних тяг 5 [23]. Для опису механіки зернового потоку ми використали теорія газової динаміки у формі відомого закону Менделєєва-Клапейрона $[1,2,18,23]$.

$$
p(y) \bar{\varepsilon}(y)=\chi\left(\frac{d u}{d y}\right)^{2}
$$

де $p(y)$ - гідростатичний тиск, $\bar{\varepsilon}(y)$ - середнє значення порозності зернового потоку, $\chi$ - коефіцієнт, який залежить від фізико-механічних властивостей досліджуваного зернового матеріалу, $\left(\frac{d u}{d y}\right)^{2}$ - квадрат швидкості переміщуваного сипкого зернового середовища.

Оскільки у формулу 1 входить ділатансія $[1,18]$ (зміна об’єму зернового матеріалу при зсувній деформації) зернового середовища при зсуві, то вона визначається:

$$
\bar{\varepsilon}(y)=\frac{1}{1-\varepsilon_{o}}
$$

де $\varepsilon_{o}$ - пористість нерухомого зернового шару $\left(\varepsilon_{o}=\frac{V_{H}-V}{V_{H}}\right.$, де $V_{\mathrm{H}}, V$-об'єм насипного шару зерна та об’єм, який займають зернини цього шару).

У дослідах використовувалось насіння таких культур, як пшениця, кукурудза і соняшник. Партія дослідного насіння зважувалася на електронних вагах і висипалась у бункер установки. Після відкриття шиберної заслінки бункера за допомогою секундоміра фіксували час руху зернового матеріалу по робочим поверхням лотків. Дослід повторяли з п'ятикратним повтором.

На першому етапі досліджувався час руху зернового матеріалу тільки по робочій поверхні розгінного лотка. На початку розгінний лоток встановлювали під кутом $\alpha=26,4^{0}$ до горизонту. На цьому куті досліджували час руху зерна пшениці стандартної вологості. Потім, на цьому ж куті досліджували рух кукурудзи та соняшнику. Визначивши середній час руху насіння пшениці, кукурудзи і соняшнику на фіксованому куті $\alpha=26,4^{0}$, необхідно змінити кут установки розгінного лотка. Після зміни кута досліди почергово повторялися.

Новий кут установки розгінного лотка визначався за такою формулою:

$$
\alpha_{i}=\arcsin \frac{B C}{A C}
$$

де $\alpha_{i}$ - новий кут установки розгінного лотка, $\mathrm{AC}=1200$ мм - робоча довжина розгінного лотка, ВС - висота нижньої частини лотка відносно горизонту. 


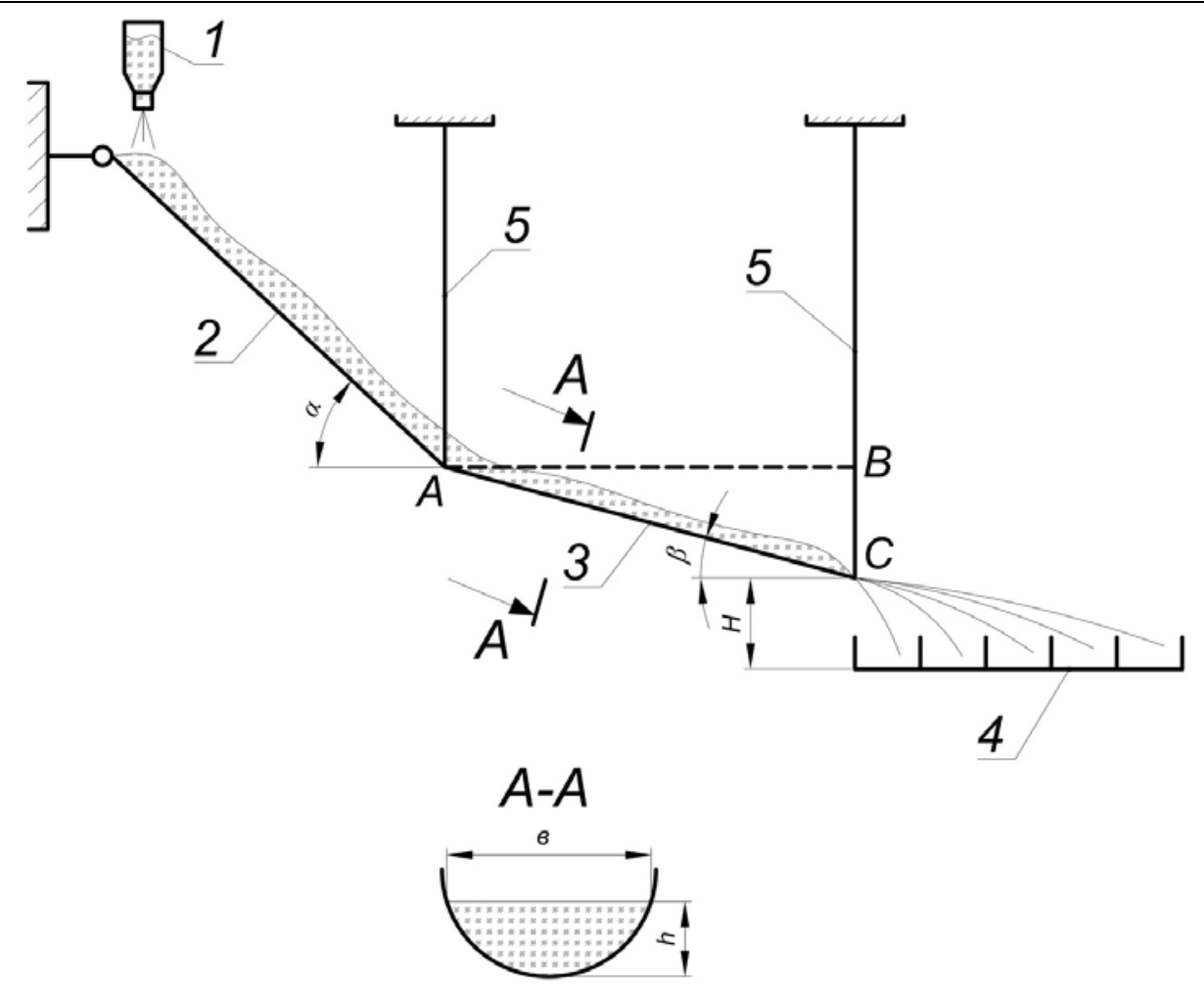

\section{Рис. 1. Гравітаційна установка з розгінним і гальмівним лотками}

На другому етапі досліджували час руху зернового матеріалу одночасно по розгінному і гальмівному лотках. Тобто розгінний і гальмівний лотки є одним робочим органом, але з різними кутами нахилу до горизонту.

При цьому загальна довжина такого лотка складає $l_{3}=2400$ мм.

Рух зерна по розгінній і гальмівній ділянці установки розглядався як ламінарна течія з різними швидкостями руху шарів. 3 рівняння нерозривності течії і зважаючи, що поперечні перерізи обох лотків однакові, отримуємо умову забезпечення стаціонарності потоку на обох ділянках $[2,3]$. Тобто кінцева швидкість потоку зерна була не меншою, ніж початкова швидкість цього потоку на початку розгінної ділянки. Така умова забезпечує проходження зернового матеріалу по обох ділянках без накопичення його на гальмівній ділянці.

Розгінній лоток установки мав довжину $l_{1}=1200$ мм, а кут установки лотку $\alpha$ вибирався більшим за кут природного відкосу досліджуваного зернового матеріалу. Довжина гальмівного лотка складала $l_{2}=1200$ мм, кут установки цього лотка до горизонту встановлювався таким чином, щоб виконувалась умова $\beta=(0,86 \ldots 0,93) \cdot \alpha_{i}$. В дослідах $\beta=0,92 \cdot \alpha_{i}$. Кути природного відкосу приймалися: для пшениці $\zeta_{n}=25^{0}$, кукурудзи $\zeta_{\kappa}=32^{0}$, соняшнику $\zeta_{c}=35^{0}[17,21,24]$.

На третьому етапі проводили дослідження, направлені на встановлення функції щільності розподілення зернового матеріалу в напрямі, паралельному центральної осі розгінного і гальмівного лотків. Для цього на порозі зсипання зерна встановлювалася кювета 4, призначена для збирання зернового матеріалу, який вилітає із сегментного каналу установки (рис. 1). Кювета складається із п'яти секцій, які розділені перегородками з відстанню 10 см одна від одної. Висота установки кювета Н відносно горизонталі складала $30 \mathrm{~cm}$, а перша комірка знаходилася на деякій відстані від порога зсипання зерна. Робоча поверхня розгінного і гальмівного каналів мали однакову шорсткість, яка забезпечувала граничне прилипання зернового матеріалу до сегментного дна лотків.

Дослідження проводили в режимах, близьких до сталого ламінарного потоку, який досягався шляхом установки гальмівного лотка під кутом близьким до кута природного відкосу зернового матеріалу, що досліджувався.

Експеримент полягав у такому. Після встановлення кута $\alpha$ розгінного лотка послідовно встановлювались кути $\beta_{1}, \beta_{2}, \beta_{3}$ гальмівного лотка. Після встановлення кутів $\alpha$ і $\beta_{1}$ в бункер 1 установки заси- 


\section{TEХНІЧНI НАУКИ}

пався зерновий матеріал. При відкритті заслінки з бункера по лоткам починався рухатися зерновий матеріал, який надходив у комірки кювети. Після закінчення руху зерна по розгінній і гальмівній ділянках з кутами $\alpha$ і $\beta_{1}$ проводилося зважування зернового матеріалу взятого з кожної комірки кювети. В першому досліді кути нахилу становили в розгінному лотку $\alpha=70,4^{0}$, а в гальмівному $\beta_{1}=67,1^{0}$. Наступні досліди проводилися аналогічно, але змінювався кут $\beta$. Зважування зернового матеріалу по кожній комірці кювети дало можливість визначити функцію щільності розподілення зернового матеріалу. Крім цього, в досліді визначали такі експериментальні дані: висота зернового шару $h$ на порозі його зсипання в кювети, ширина верхнього шару зерна $b$, час заповнення комірок, відстань $H$ між порогом зсипання і кюветом та кути нахилу розгінного і гальмівного лотків $\alpha$ і $\beta$.

\section{Результати досліджень та їх обговорення}

На рис. 2 наведені графіки залежності зміни часу руху пшениці, кукурудзи і соняшнику по робочій поверхні лотка до повного їх сходу, від кута установки розгінного лотка відносно горизонту. При цьому секундна подача пшениці на робочу частину розгінного лотка становить $q_{\text {п }}=0,262$ кг/c, відповідно кукурудзи $q_{\mathrm{\kappa}}=0,244 \mathrm{\kappa} / \mathrm{c}$, а соняшника $q_{\mathrm{c}}=0,286$ кг $/ \mathrm{c}$.

Після обробки експериментальних даних були отримані такі рівняння регресії:

для зерна пшениці

для зерна кукурудзи

$$
t_{n}=-0,291 \cdot \alpha+16,33
$$

для зерна соняшнику

$$
t_{\kappa}=-0,265 \cdot \alpha+14,87
$$

$$
t_{c}=-0,308 \cdot \alpha+18,40 .
$$

Результати досліджень свідчать, що рух зернового матеріалу в розгінному лотку відбувається суцільним потоком з постійною глибиною $h$. Час руху зернового матеріалу залежить від кута встановлення розгінного лотка відносно горизонту. Крім того, швидкість спуску зерна залежить від форми і маси зернівок та коефіцієнта тертя і матеріалу, з якого виготовлений лоток. Встановлено, що найшвидше з лотка спускається насіння кукурудзи, а повільніше соняшнику.

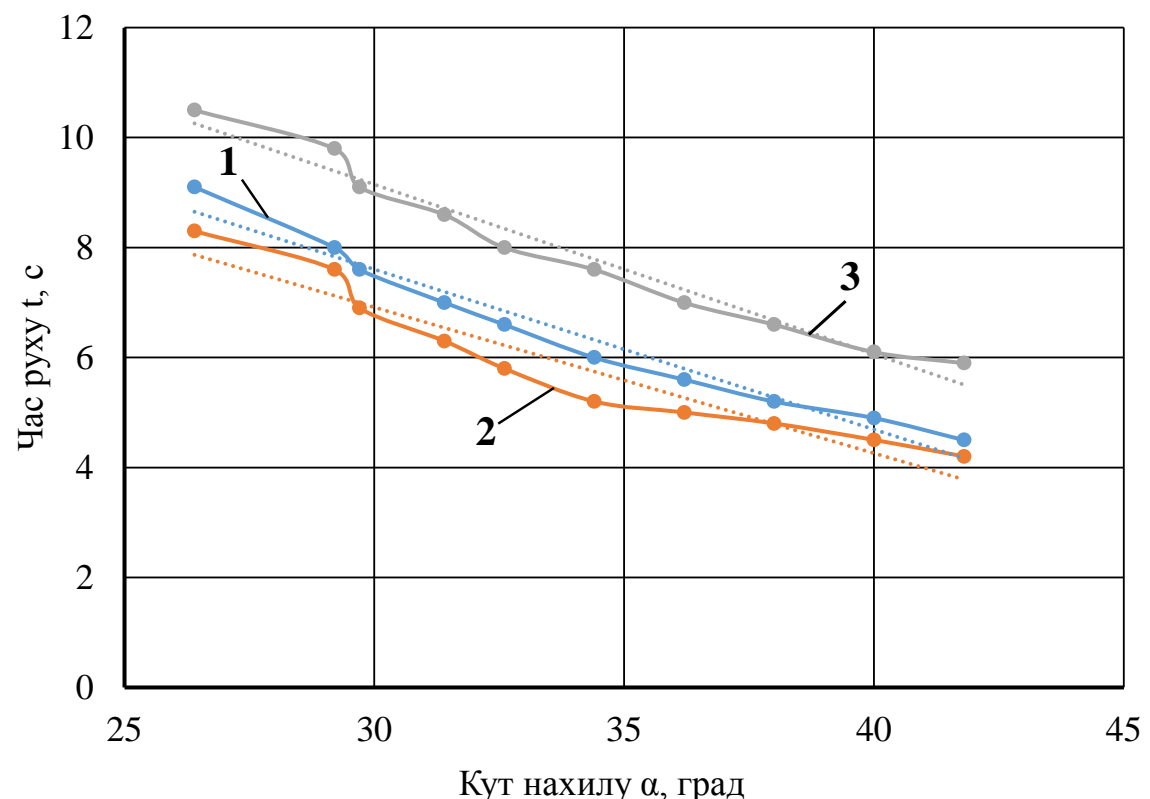

1 - пшениця; 2 - кукурудза; 3 - соняшник.

Рис. 2. Залежність часу спуску зернового матеріалу в розгінному лотку від кутів його установки відносно горизонту

Якщо досліджувати рух пшениці одночасно по розгінному і гальмівному лотках з різними кутами нахилу до горизонту, то час проходження ії по робочим поверхням змінюється по-різному (табл. 1). 
Довжина робочих поверхонь лотків рівна між собою.

3 таблиці видно, що зі збільшенням кутів $\alpha$ і $\beta$ час спуску пшениці по робочих поверхнях установки зменшується. Для забезпечення повільного спуску зернового матеріалу в нижній частині силосу необхідно, щоб кут $\alpha$ мав максимальне значення, а кут $\beta$ мінімальне. Наприклад, для пшениці $\alpha=43^{0}$, а $\beta=32^{0}$.

При дослідженні руху кукурудзи по розгінному лотку з кутом установки $\alpha=70,4^{0}$ до горизонту 3 переходом руху кукурудзи на гальмівний лоток, який встановлено під кутом $\beta=67,1^{0}$, виявлено, що час руху по рівним ділянкам пристрою різний. На першій розгінній ділянці час руху зернового матеріалу в 1,219 раза більший. ніж на гальмівній ділянці. При зміні кута $\beta$ на нову величину $\beta=63,8^{0}$, час руху зернового матеріалу у 1.328 разів більший, ніж на гальмівній. При зміні кута $\beta$ в бік його зменшення спостерігається постійне збільшення сегментного профілю зернового потоку.

\section{1. Зміна часу руху пшениці стандартної вологості в розгінному і гальмівному лотках,} $\left(l_{1}=I_{2}=1200 \mathrm{Mm}\right)$

\begin{tabular}{|c|c|c|c|c|}
\hline \multirow{2}{*}{\multicolumn{2}{|c|}{$\begin{array}{c}\text { Величина кута установки розгінно- } \\
\text { го і гальмівного лотків відносно } \\
\text { горизонту, град }\end{array}$}} & \multicolumn{2}{|c|}{$\begin{array}{c}\text { Час проходження насіння пшениці по } \\
\text { робочим поверхням лотків, с }\end{array}$} & \multirow{3}{*}{$\begin{array}{c}\text { Сумарний час } \\
\text { руху насіння } \\
\text { пшениці, с }\end{array}$} \\
\hline & & розгінна ділянка & гальмівна ділянка & \\
\hline$\alpha$ & $\beta$ & $t_{1}$ & $t_{2}$ & \\
\hline 35 & 32 & 6,0 & 8,2 & 14,2 \\
\hline 37 & 34 & 5,5 & 7,1 & 12,6 \\
\hline 39 & 36 & 5,1 & 6,5 & 11,6 \\
\hline 41 & 38 & 4,4 & 6,3 & 10,7 \\
\hline 43 & 40 & 4,2 & 5,6 & 9,8 \\
\hline
\end{tabular}

Завантаживши в бункер 1,0 кг насіння соняшнику стандартної вологості, визначили секундну подачу насіння на розгінний лоток. При діаметрі вихідного отвору бункера 40 мм вона склала $q_{c}=$ 0,286 кг с. Встановивши розгінний лоток під кутом $\alpha=41^{0}$, а гальмівний під кутом $\beta=38^{0}$, визначили час руху насіння соняшнику по робочим поверхням лотків. Час руху склав, відповідно $t_{1}=7,1 \mathrm{c}, t_{2}=$ 10,3 с. Коли кут $\beta \leq \zeta$ відбувається інтенсивне гальмування зернового потоку і зерно повністю заповнює гальмівний і розгінний канали і відбувається пересипається зерна через краї лотків.

Діаграма щільності розподілення насіння кукурудзи в напрямі паралельному центральної осі гальмівного лотка наведена на рис. 3 .

Із діаграми видно, що зерно кукурудзи, яке рухається в нижній частині лотка на порозі зсипання має найменшу швидкість, тобто воно потрапляє в найближчі комірки кювети. Зерно верхніх шарів має більшу швидкість, тому воно потрапляє в дальні комірки кювети.

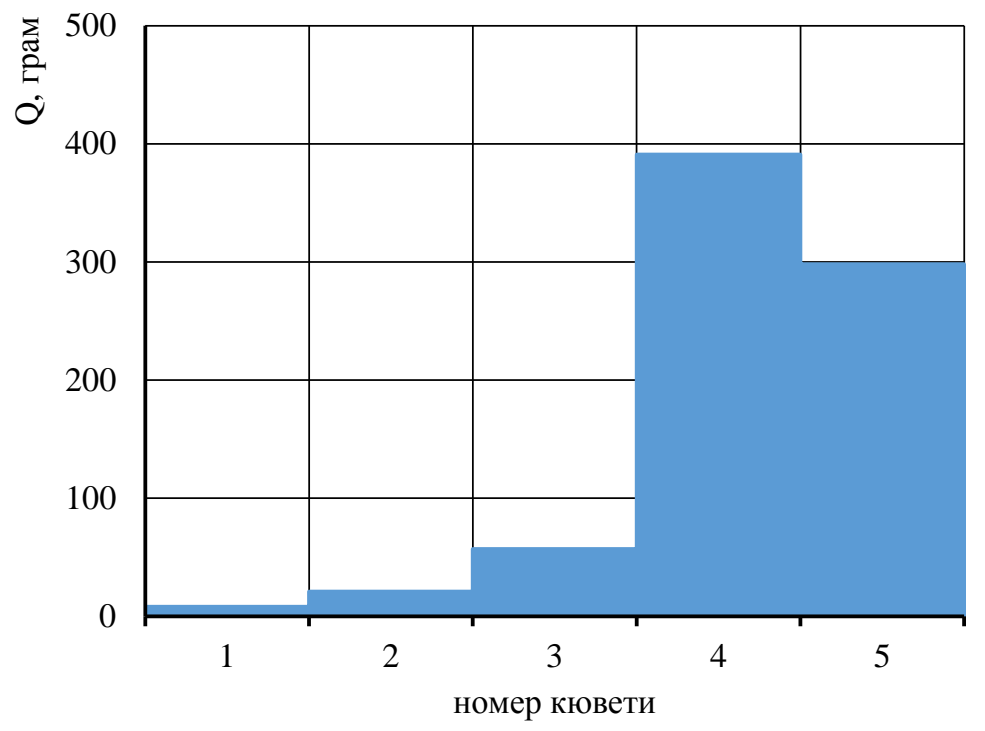

Рис. 3. Щільність розподілення насіння кукурудзи по кюветам 
Висновки

Виявлено, що для нормальної роботи гравітаційної установки 3 дискретно змінними кутами нахилу лотків до горизонту необхідно, щоб кути нахилу розгінного і гальмівного лотків біли більші від кутів природного відкосу досліджуваного зернового матеріалу. Причому бажано, щоб кут нахилу розгінного лотка був набагато більшим від кута природного відкосу зернового матеріалу. Тоді як кут нахилу гальмівного лотка повинен бути в 1,22 раза більшим від кута природного відкосу зерна. Зменшення кута нахилу гальмівного лотка відносно горизонту призводить до інтенсивного гальмування зернового потоку, внаслідок чого різко починає збільшуватися об'єм зерна в лотках. Збільшення зерна в лотках приводить до пересипання зерна через краї лотків.

Перспективи подальших досліджень Подальші дослідження будуть направлені на виявлення ефективних кутів розгінної і гальмівної ділянок спірального завантажувача силосів зерном. Планується провести дослідження з визначення втрат енергії внаслідок зіткнення зернин одна з одною в зерновому потоці особливо при переході їх із розгінної на гальмівну ділянку гравітаційної установки.

\section{References}

1. Dolgunin, V. N., \& Borshhev, V. Y. (2005). Bystrye gravitacionnye techeniya zernistyx materialov: texnika izmereniya, zakonomernosti, texnologicheskoe primenenie. Moskva: Izdatelstvo Mashinostroenie - 1 [In Russian].

2. Sevidzh, S. (1985). Gravitacionnoe techenie nesvyazannyx granulirovannyx materialov v lotkax i kanalax. Mexanika granulirovannyx sred: Teoriya bystryx dvizhenij, 86-146 [In Russian].

3. Tishhenko, L. N. (2004). Intensifikaciya separirovaniya zerna. Xarkov: nauchnaya kniga [In Russian].

4. Samoilenko, T. V., Arendarenko, V. M., \& Antonets, A. V. (2020). Kinematyka rukhu zerna po spiralnomu prystroiu zi zminnym kutom spusku. Visnyk Poltavskoi Derzhavnoi Ahrarnoi Akademii, 1, 267-274. doi: 10.31210/visnyk2020.01.31 [In Ukrainian].

5. Moya, M., Aguado, P. J., \& Ayuga, F. (2013). Mechanical properties of some granular agricultural materials used in silo design. International Agrophysics, 27 (2), 181-193. doi: 10.2478/v10247-012-0084-9

6. Strona, I. G., \& Pugachev, A. N. (1972). Travmirovaniya semyan i ego povrezhdenie. Moskva: Kolos [In Russian].

7. Negi, S. C., Lu, Z., \& Jofriet, J. C. (1997). A numerical model for flow of granular materials in silos. Part 2: model validation. Journal of Agricultural Engineering Research, 68 (3), 231-236. doi: 10.1006/jaer.1997.0197

8. Samoilenko, T. V., Ivanov, O. M., Melnyk, V. I., \& Arendarenko, V. M. (2018). Patent Ukrainy № 129364. Kyiv: Ukrainskyi instytut intelektualnoi vlasnosti [In Ukrainian].

9. Tverdokhlib, I. V. (2017). Dynamika rukhu chastynky v sypkomu zernovomu seredovyshchi. Vibratsiia $v$ Tekhnitsi ta Tekhnolohiiakh, 3, 128-135 [In Ukrainian].

10. Melnyk, V. I., \& Samoilenko, T. V. (2018). Analiz napriamiv udoskonalennia konstruktsii prystroiv dlia zavantazhennia sylosiv. Inzheneriia Pryrodokorystuvannia, 1, 83-91 [In Ukrainian].

11. Mosina, N. N. (2004). Sovershenstvovanie zagruzki xranilishh i podvizhnogo sostava sypuchimi gruzami. Candidate's thesis. Sankt - Peterburg - Pushkin [In Russian].

12. Arendarenko, V. M., \& Samoilenko, T. V. (2018). Matematychne modeliuvannia protsesu zavantazhennia sylosiv zernom. Visnyk Poltavskoi Derzhavnoi Ahrarnoi Akademii, 2, 158-161 [In Ukrainian].

13. Mosina, N. N. (2003). Metodika opredeleniya pokazatelej processa zagruzki bunkera sypuchim materialom. Sovremennye texnologii, sredstva mexanizacii i texnicheskoe obsluzhivanie v APK, (55-57). Samara: Samarskaya gosudarstvennaya selskoxozyajstvennaya akademiya [In Russian].

14. Borshhev, V. Y., \& Dolgunin, V. N. (2006). Harakteristiki sdvigovogo potoka zernistoj sredy i rekomendacii po organizacii texnologicheskix processov. Vestnik Tambovskogo Gosudarstvennogo Tekhnicheskogo Universiteta, 2, 401-408 [In Russian].

15. Tarasenko, A. P. (2003). Snizhenie travmirovaniya semyan pri uborke i posleuborochnoj obrabotke. Voronezh: FGOU VPO Voronezhskij GAU [In Russian].

16. Boiko, D. I. (2008). Rivniannia dynamika sypkoho materialu v robochii zoni zmishuvacha ta yoho rishennia. Tekhnichnyi Servis Ahropromyslovoho, Lisovoho ta Transportnoho Kompleksiv, 2, 75-82 [In Ukrainian].

17. Zenkov, R. L. (1964). Mexanika nasypnyx gruzov. Moskva: Mashinostroenie [In Russian]. 
18. Sous, S. (1971). Gidrodinamika mnogofaznyx sistem. Moskva: Mir [In Russian].

19. Borshhev, V. Y., Dolgunin, V. N., \& Dronov, M. Y. (2005). Kaskadnaya gravitacionnaya separaciya zernovyx materialov: osobennosti texnologii i modelirovanie. Vestnik Tambovskogo Gosudarstvennogo Tekhnicheskogo Universiteta, 11, 903-909 [In Russian].

20. Dolgunin, V. N., Ukolov, A. A., \& Klassen, V. P. (1992). Model mexanizma segregacii pri bystrom gravitacionnom techenii chasticz. Teoreticheskie Osnovy Ximicheskix Texnologij, 5, 100-109 [In Russian].

21. Arendarenko, V.M., \& Antonets, A.V. (2020). Shvydkist rukhu zernovoho potoku po spiralnomu prystroiu iz zminnym kutom spusku. Vseukrainska naukovo-praktychna konferentsiia molodykh vchenykh, studentiv ta aspirantiv, (72-75). Poltava: RVV PDAA [In Ukrainian].

22. Cheng, X., Gao, M., Hu, M., \& Du, X. (2019). The Simulation of static stress distribution of wheat piles in silos by the modified Cam-clay model. International Agrophysics, 33 (1), 11-19. doi: 10.31545/intagr/103749

23. Arendarenko, V. M., Antonets, A. V., Savchenko, N. K., \& Ivanov, O. M. (2020). Rozrakhunkova model hravitatsiinoho rukhu zernovoho materialu u pokhylomu kanali zi dyskretno zminnym kutom nakhylu. Visnyk Poltavskoi derzhavnoi ahrarnoi akademii, 4, 273-282. doi: 10.31210/visnyk2020.04.35 [In Ukrainian].

24. Trisvinskij, L. A. (1985). Xranenie zerna. Moskva: Agropromizdat [In Russian].

25. Arendarenko, V. M., \& Samoilenko, T. V. (2020). Sposoby zavantazhennia sylosiv zernovym materialom. Vseukrainska naukovo-praktychna konferentsiia molodykh vchenykh, studentiv ta aspirantiv, (52-54). Poltava [In Ukrainian].

26. Flehantov, L. O., \& Antonets, A. V. (2017). Kompyuterne modelyuvannya mekhanichnoho rukhu tila zasobamy MATHCAD. Informatsiyni Tekhnolohiyi $v$ Osviti, 30, 97-109. doi: 10.14308/ite000622 [In Ukrainian].

\section{Стаття надійшла до редакції 30.01.2021 р.}

Бібліографічний опис для цитування:

Арендаренко В. М., Самойленко Т. В., Іванов О. М. Дослідження руху зернового матеріалу по лоткам гравітаційної установки. Вісник ПДАА. 2021. № 1. С. 302-309.

(C) Арендаренко Володимир Миколайович,Самойленко Тетяна Володимирівна, Іванов Олег Миколайович, 2021 
Відповідальний редактор: Мельничук $B . B$.

Літературні редактори: Дедухно А. B.

Переклад англійською мовою: Панкова T. O.

Куратор з індексів DOI: Жукова В. K.

Комп'ютерна верстка та дизайн: Свєшнікова A. O.

Під час створення макету було використано матеріали, які знаходяться у вільному доступі мережі Інтернет.

Формат 60х90/8. Ум. друк. арк. 22. Тираж 300 пр. Зам. № 33.

Видавець і виготовлювач: Полтавська державна аграрна академія.

Адреса: 36003, м. Полтава, вул. Григорія Сковороди, 1/3.

Свідоцтво суб'єкта видавничої справи ДК № 2174 від 26.04.2005 р. 